KHAZANAH MULTIDISIPLIN

VOL 1 NO 22020

https://journal.uinsgd.ac.id/index.php/kl

\title{
PERAN PEMERINTAH DESA DALAM UPAYA MENCEGAH PERNIKAHAN ANAK DI MASYARAKAT MADURA
}

\author{
Raudlatun, Khairul Asiah \\ STKIP PGRI Sumenep, Jl. Trunojoyo, Gedungan Barat, Gedungan, Batuan, \\ Kabupaten Sumenep, Jawa Timur 69451 \\ E-mail: raudlatun@ stkippgrisumenep.ac.id
}

Diterima : 30 September 2020, Revisi : 1 November 2020 Disetujui : 5 November 2020

\begin{abstract}
Recently, child marriage is still a very strong tradition in the surrounding environment, especially in Rubaru District, Sumenep Regency. Child marriage is a common problem that must be resolved, because the observation of the majority of researchers who marry off their children at an early age are parents who do not have higher education, of course, will have a very negative impact on their children such as dropping out of school, economically weak. This is where the role of the village government is needed. The purpose of this study is to determine the factors that influence the community to carry out child marriage and what impact is felt by couples who marry at a young age. The most urgent objective is how the role and response of the local village government in efforts to prevent child marriage. This type of research used in this research is qualitative research. The nature of the research is descriptive-analytic. The data sources used are primary data sources obtained from interviews with the local village government and perpetrators of child marriage, secondary data sources obtained from books and other sources related to research and tertiary data sources. And data collection techniques through observation, interviews and documentation.In this study, several factors and impacts of child marriage were found, as well as the role of the village government in efforts to prevent child marriage. Because of the three villages sampled in this study, the village government which has several instruments such as the Apel (head of the hamlet) has a very important role in minimizing the occurrence of child marriage.
\end{abstract}

Keywords: Village Government, Efforts to Prevent, child marriage

\begin{abstract}
ABSTRAK
Akhir-akhir ini nikah anak masih menjadi tradisi yang sangat kuat di lingkungan sekitar, khususnya di Kecamatan Rubaru Kabupaten Sumenep. Nikah anak menjadi masalah bersama yang harus dipecahkan, karena pengamatan peneliti mayoritas yang menikahkan anaknya di usia dini adalah orang tua yang tidak memiliki pendidikan tinggi, tentunya akan memberikan dampakyang sangat negative terhadap anaknya seperti putus sekolah, lemah secara ekonomi. Disinilah peran pemerintah desa sangat dibutuhkan. Adapun tujuan penelitian ini yaitu untuk mengetahui Faktor-faktor yang mempengaruhi masyarakat melakukan pernikahan anak dan dampak apa yang dirasakan pasangan yang melakukan pernikahan usia muda. Serta tujuan yang paling urgen adalah bagaimana peran dan respon pemerintah desa setempat dalam upaya mencegah pernikahan anak. Jenis penelitian yang digunakan dalam penelitian ini adalah penelitian kualitatif. Sifat penelitiannya bersifat deskriptif-analitik. Sumber data yang digunakan ialah sumber data primer yang diperoleh dari hasil wawancara dengan pemerintah desa setempat, dan pelaku pernikahan anak, sumber data sekunder yang diperoleh dari buku-buku dan sumber lainnya yang berkaitan dengan penelitian dan sumber data tersier. Dan teknik pengumpulan datanya melalui observasi, wawancara dan dokumentasi.Dalam penelitian ini didapatkan beberapa factor dan dampak pernikahan anak, begitu juga
\end{abstract}




\section{KHAZANAH MULTIDISIPLIN}

VOL 1 NO 22020

https://journal.uinsgd.ac.id/index.php/kl

dengan peran pemerintah desa dalam upaya pencegahan pernikahan anak. Karena dari tiga desa yang menjadi sampel dalam penelitian ini, pemerintah desa yang memeiliki beberapa perangkat seperti Apel (kepala Dusun) memiliki peran yang sangat penting dalam meminimalisir terjadinya nikah anak.

Kata Kunci : Pemerintah Desa, Upaya Mencegah, pernikahan anak

\section{PENDAHULUAN}

Menurut Mubasyaroh (2016) Setiap makhluk diciptakan berpasangpasangan untuk saling menyayangi dan mengasihi. Ungkapan ini menunjukkan bahwa hal ini akan terjadi dengan baik melalui hubungan pernikahan, dalam rangka membentuk keluarga yang sakinah. Keluarga pada dasarnya merupakan upaya untuk memperoleh kebahagian dan kesejahteraan hidup, keluarga dibentuk untuk memadukan rasa kasih dan sayang diantara dua makhluk berlainan jenis yang berlanjut untuk menyebarkan rasa kasih dan sayang keibuan dan keayahan terhadap seluruh anggota keluarga (anak keturunan). Semuanyajelas-jelas bermuara pada keinginan manusia untuk hidup lebih bahagia dan lebih sejahtera (Mubasyaroh, 2016).

Artinya, setiap manusia yang akan menikah harus siap lahir dan batin, matang secara biologis dan pskologis. Menikah pada usia yang sangat ideal menurut Undang-undang Perkawinan nomor 16 Tahun 2019 yakni laki-laki dan perempuan berusia 19 tahun, sehingga tujuan menikah dapat dicapai.

Sementara itu di Indonesia, pernikahan anak sudah menjadi fenomena nasional, budaya menjadi faktor yang berpengaruh besar terhadap pola kehidupan dalam masyarakat, termasuk dalam pernikahan usia dini ini (Ana Latifatul Muntamah, 2016). Bahkan Perkawinan anak, atau sering juga disebut perkawinan dini, merupakan praktik tradisional yang telah lama dikenal dan tersebar luas di seluruh belahan dunia (Djamilah, 2014).

Namun fenomena dan praktik pernikahan anak perempuan juga banyak dilakukan di Pulau Madura. Berdasarkan observasi awal peneliti , rata-rata penduduk Madura melakukan praktik pernikahan anak 


\section{KHAZANAH MULTIDISIPLIN}

VOL 1 NO 22020

https://journal.uinsgd.ac.id/index.php/kl

perempuan ini. Bahkan ada yang menikahkan anaknya sejak usia 12 tahun. Praktek perkawinan anak tersebut terjadi merata di 4 Kabupaten di Madura. Hukum adat di Madura masih membolehkan praktek tersebut. Tradisi pernikahan anak di Madura diawali dengan adanya abhakalan yang memiliki makna tunangan (Dessy Trisilowaty, 2019).

Masyarakat Madura memiliki banyak budaya yang masih dilestarikan sampai saat ini, salah satunya adalah pernikahan anak tersebut (Munawara: 2015). Perkawinan usia dini atau pernikahan anak saat ini bisa dilihat dari pelbagai wilayah apa lagi pedesaan. Masyarakat pedesaan cenderung akan melakukan perkawinan dini. Hal ini dikarenakan masyarakat pedesaan sebagian besar masih memegang paham lama yang koserpatif dan masih pada prinsip yang merujuk pada budaya, yang sudah tertanam pada masyarakat desa dalam hubungan perkawinan. Hal tersebut yang mendukung masyarakat untuk tetap melakukan perkawinan usia dini yang sampai saat ini terjadi dan mudah ditemukan di wilayah pedesaan (Ilham Hidayatulloh., et al, 2018).

Tepatnya di Desa Karngnangka, Mandala dan Tambaksari Kecamatan Rubaru Sumenep, Madura pernikahan anak tersebut masih tetap dilaksanakan dan menjadi hukum adat masyarakat. Sehingga pelaksanaannya pun masih dianggap sah-sah saja, meski pun pada kenyataannya hukum adat kebiasaan masyarakat tersebut bertentangan dengan hukum negara yang notabennya sudah menegaskan secara jelas tentang Undang-Undang Nomor 16 Tahun 2019 tentang perubahan Undang-Undang No. 1 Tahun 1974 tentang Perkawinan. Undang-undang tersebut menjelaskan bahwa perkawinan hanya boleh dilaksanakan oleh perempuan dan laki-laki yang berumur 19 tahun.

Banyak faktor yang mempengaruhi terjadinya pernikahan dini, di antaranya adalah keinginan anak yang bersangkutan, keinginan orang tua, "kecelakaan" yang diakibatkan oleh hubungan intim di luar kontrol atau mungkin pandangan masyarakat yang membuat orang tua khawatir putrinya dianggap perawan tua. (Eni Zulfa Hidayah, 2014). 


\section{KHAZANAH MULTIDISIPLIN}

VOL 1 NO 22020

https://journal.uinsgd.ac.id/index.php/kl

Nikah anak menjadi masalah kompleks dan harus diselesaikan secara bersama, peneliti mengamati beberapa kejadian yang terjadi di sekitar, maka peneliti sangat tertarik untuk melakukan penelitian lebih lanjut tentang peran pemerintah desa dalam upaya mencegah nikah anak. Peneliti pada tahun 2019 telah melakukan penelitian tentang fenomena nikah anak, namun saat ini lebih focus pada peran pemerintah desa.

Beberapa penelitian sebelumnya yang dikaji dalam rangka menentukan positioning penelitian ini adalah sebagai berikut. Djamilah, Reni Kartikawati (2014), Dampak Perkawinan Anak di Indonesia.Jurnal Studi Pemuda Vol 3 No 1 Mei 2014.Hasil penelitian menunjukkan bahwa perkawinan anak terjadi karena kurangnya pendidikan kesehatan reproduksi dan seksual (PKRS) yang komprehensif sejak anak Mohammad (2011),Perkawinan Anak di Bawah Umur (Sebuah Kajian PerspektifHukum Islam).Jurnal Al-Ihkam Vol 6 No 2 Desember 2011. Hasil penelitian menunjukkan bahwa memang terjadi perbedaan antara hukum Negara dan hukum Islam. Sherlin Darondos (2014), Perkawinan Anak di Bawah Umur dan Akibat Hukumnya.Jurnal Lex et Societatis Vol II/No. 4/Mei/2014. Hasil penelitian menunjukkan bahwahukum adat tidak mengenal batas umur dewasa. Hukum Islam tidak menyebut secara spesifik batasan umur. Candraningrum Dewi dkk, 2016, Takut akan Zina, Pendidikan Rendah, dan Kemiskinan :Status Anak Perempuan dalam Pernikahan Anak di Sukabumi Jawa Barat. Jurnal Perempuan, Vol 21 No 1 Februari 2016.Hasil penelitian menunjukkan bahwa faktor penyebab perkawinan anak karena takut zina, pendidikan rendah dan kemiskinan. Mies Grijn dkk, 2016.Pernikahan Anak di Sukabumi Jawa Barat. Jurnal Perempuan Vol 21 No 1 Februari 2016. Hasil penelitian menunjukkan bahwa penyebab perkawinan anak karena kurangnya kontrol seksualitas perempuan, takut zina, lemahnya akses terhadap pendidikan dan kesehatan

Penelitian ini berbeda dari penelitian lainnya karena penelitian ini berfokus pada upaya pencegahan pernikahan anak usia dini dan dengan objek penelitian yang berbedapula yaitu pada Kecamatan Rubaru 
KHAZANAH MULTIDISIPLIN

VOL 1 NO 22020

https://journal.uinsgd.ac.id/index.php/kl

Kabupaten Sumenep.

\section{METODE PENELITIAN}

Studi ini didasari dari metode studi literatur, salah satu metode penelitian dengan mengumpulkan, membaca, serta mencatat studi kepustakaan yang terkait dengan penelitian, lalu mengelolanya sebagai dasar untuk membangun kerangka judul dengan kesatuan yang utuh ( Creswel:2016). Menggunakan pendekatan kualitatif serta studi lapangan untuk mendapatkan data secara lebih mendalam.

\section{HASIL DAN PEMBAHASAN}

\section{Bentuk Pernikahan Anak yang Terjadi di Kecamatan Rubaru Selayang Pandang Tentang Kecamatan Rubaru}

Rubaru adalah salah satu kecamatan di kabupaten Sumenep yang memiliki 11 desa. Mayoritas masyarakat Rubaru yaitu petani. Peneliti mengambil tiga desa sebagai sampel dalam penelitian ini, yaitu Mandala, Karangnangka dan Tambaksari.

\section{Ragam Bentuk Pernikahan Anak}

Peneliti mengambiltiga desa sebagai sampel dalam kasus nikah anak yang terjadi di kecamatan Rubaru, yaitu desa Mandala, Karangnangka dan Tambaksari. Dari hasil wawancara peneliti dengan KUA Kecamatan Rubaru pada tanggal 02 April 2020, menyatakan bahwa bentuk pernikahan anak itu salah satunya karena kemauan sendiri, ataupun usianya masih belum mencukupi sesuai dengan aturan perundang-undangan, sehingga si anak itu harus mengurus dispensasi pernikahn ke KUA, dengan proses dari pihak desa mengajukan permohonan dengan melengkapi berbagai persyaratan, setelah dicek berkasnya maka akan ada surat penolakan dari KUA karena usia belum mencukupi, namun ada sebagian masyarakat yang tidak kembali mengurus dispensasi karena keterbatasan dana, sehingga masyarakat melakukan nikah sirri dan itu diluar control KUA.

Dari ketiga desa yang menjadi sampel peneliti, terdapat beberapa kasus yang sedang diproses surat dispensasinya, dan ada juga yang su dah memperolah putusan dari pengadilan sehingga KUA bisa memproses 
KHAZANAH MULTIDISIPLIN

VOL 1 NO 22020

https://journal.uinsgd.ac.id/index.php/kl

pernikahnnya secara normative.

\section{Faktor-faktor Terjadinya Pernikahan Anak di Kecamatan Rubaru}

Dari hasil wawancara bersama pemerintah desa Mandala (13 April 2020), Karangnangka (04 Mei 2020) dan Tambaksari (22 Mei 2020), peneliti dapat mengklasifikasikan factor-faktor terjadinya nikah anak :

\section{Kemauan sendiri}

Anak zaman sekarang sangatlah berbeda dengan anak zaman dulu, saat ini anak-anak selalu bersanding dengan HP android, tentunya hal itu menyebabkan adanya hubungan dengan lawan jenisnya, dan hal ini yang mendorong anak-anak untuk menikah di usia dini walaupun secara usia belum matang.

\section{Takut zina atau terjadi fitnah}

Orang tua ataupun masyarakat sekitar melihat anak-anaknya yang selalu berdua baik boncengan sepeda motor atau di rumahnya, maka orang tua terutama ibu akan mendesak anaknya untuk segera menikah walaupun secara usia belum memenuhi syarat, padahal nikah itu bukanlah solusi satu-satunya. Seharusnya orang tuanya mampu mendampingi anaknya, dan memeberikan pemahaman tentang pola relasi dan komunikasi dengan lawan jenisnya.

\section{Kakeknya atau neneknya khawatir tidak nututi ke acara pernikahan cucunya}

Di Madura khususnya di Sumenep terdapat tradisi karjeh (pesta pernikahan) dimana setiap orang bias menyumbangkan uang yang diakad dengan rokok, beras, gula dan sembako yang lainnya, ini dinamakan “persatuan” yang dibukukan dalam kwitansi. Sehingga ketika satu keluarga memiliki ratusan kwitansi maka orang tua itu akan menikahkan anaknya dengan alas an khawatir nenek atau kakeknya tidak nututi ke acara pengantenan anaknya.

\section{Eseddek deri se lakek (didesak oleh pihak laki-laki)}

Factor ini seakan-akan menjadi alas an yang sangat sensitive, karena 
KHAZANAH MULTIDISIPLIN

VOL 1 NO 22020

https://journal.uinsgd.ac.id/index.php/kl

ketika pihak perempuan menolak desakan dari pihak laki-laki maka perempuan itu akan takancheng (terkunci), artinya seumur hidupnya dia tidak akan bias menerima lamaran dari orang lain karena sudah menolak ajakan dari pihak laki-laki untuk menikah.

\section{Tradisi abhekalan (tunangan)}

Tunangan sejak dini masih menjadi tradisi di lungkungan masyarakat sekitar, baik tunangan dengan saudaranya sendiri, ataupun dengan tetangga sekitar. Ketika ada anak yang belum tunangan maka aka nada persepsi bebinik tak pajuh (perempuan itu tidak laku). Sehingga si perempuan itu akan ditunangkan oleh orang tuanya.

\section{Dampak-dampak Terjadinya Pernikahan Anak di Kecamatan Rubaru}

Dari enam sampel kasus nikah anak yang terjadi di Kecamatan Rubaru, peneliti dapat mendeskripsikan beberapa dampak nikah anak :

\section{Putus sekolah atau Drop out}

Dari hasil penelitian yang dilakukan, enam kasus itu rata-rata putus sekolah, dengan alasan malu ataupun tidak diizinkan oleh suaminya. Ketika si anak sudah menikah maka dia akan terbebani dengan urusan keluarga sehingga hal ini juga mengakibatkan putus sekolah.

Ada satu kasus di desa Tambaksari, dia kelahiran tahun 2003, menikah tahun 2019 saat usia 17 tahun atau baru lulus SMP, anak ini dijodohkan oleh neneknya, tidak tahu secara detail tentang calonnya, hal ini mengakibatkan dia putus sekolah, dan saat ini dia sedang mengurus perceraiannya.

\section{Kekerasan dalam Rumah Tangga (KDRT)}

Kekerasan itu terdapat beberapa macam; kekerasan fisik, kekerasan psikis, kekerasan verbal dan kekerasan ekonomi. Dari beberapa kasus yang menjadi sampel, sangat beragam kekerasan yang dialaminya, terutama bagi perempuan. Si anak mengalami kekerasan ekonomi, tidak dinafkahi oleh suaminya. Bahkan ada satu anak dari desa Karangnangka yang menikah di usia 14 tahun pada tahun 2018, saat ini dia sudah cerai dengan suaminya 
KHAZANAH MULTIDISIPLIN

VOL 1 NO 22020

https://journal.uinsgd.ac.id/index.php/kl

yang pertama, cerai mati dengan suaminya yang kedua, dan dia menikah lagi dengan laki-laki yang pekerjaannya serabutan.

\section{Kesehatan}

Menikah di usia dini, tentunya secara kesehatan belum matang, artinya Rahim belum siap dibuahi. Salah satu kasus yang ada di kecamatan Rubaru tepatnya di desa Karangnangka perempuan usia 14 tahun yang saat ini hamil dan pernah mengalami pendarahan. Bahkan yang sangat menegrikan anak usia 14 tahunan sudah mengikuti program KB untuk menunda kehamilannya.

\section{Peran Pemerintah Desa dalam Upaya Mencegah Pernikahan Anak di Kecamatan Rubaru}

\section{Sosialisasi}

Dari ketiga desa yang diteliti, semua desa telah melakukan sosialisasi tentang Undang-undang No 16 tahun 2019 tentang perkawinan, perubahan atas Undang-undang No 1 tahun 1974, dimana usia nikah untuk laki-laki dan perempuan harus mencapai 19 tahun. Kagiatan ini dilakukan melalui RT, ketika kepala desa menyampaikan sambutan di acara-acara perkawinan, atau kegiatan kompolan. Dan yang paling unik lagi adalah siaran melalui sound system di balai desa tentang batas usia menikah dan dampak-dampak pernikahan anak. Hal ini dilakukan secara rutin setiap minggu sekali.

\section{Meningkatkan peran apel (kepala dusun)}

Setiap desa memiliki dusun, Karangnangka memiliki tiga dusun yaitu Dusun Nangke', Dusun Talaga dan Dusun Langgar, Sedangkan Mandala dan Tambaksari memiliki empat dusun. Kepala Dusun atau yang familiar disebut dengan Apel sangat memiliki peran penting dalam upaya mencegah nikah anak, apel sebagai garda terdepan dalam meminimalisir nikah usia dini, karena kepala dusun sangat dekat dengan masyarakat grassroot. Ketika ada warga yang ingin menikahkan anaknya di usia dini, maka apel akan memediasi keluarga tersebut untukmenahan keinginannya terlebih dahulu, dan peran apel dalam memberikan pendidikan pencegahan 
KHAZANAH MULTIDISIPLIN

VOL 1 NO 22020

https://journal.uinsgd.ac.id/index.php/kl

nikah anak dengan memberikan gambaran tentang dampak nikah anak, sehingga orang tersebut dapat menunda keinginannya.

\section{Pendidikan tentang kesehatan reproduksi bagi remaja}

Desa bekerjasama dengan bidan dan puskesmas dalam rangka memberikan pendidikan kesehatan reproduksi bagi remaja, tujuannya untuk memberi pemahaman kepada remaja bahwa kesehatan reproduksi itu sangat penting, artinya ketika usia masih dibawah 19 tahun maka secara medis belum matang, sehingga tidak siap untuk dibuahi.

\section{Adanya forum mediasi untuk menunda pernikahannya}

Forum ini dibuat oleh apel yang diinisiasi kepala desa, tentunya forum ini sangat memberikan manfaat kepada warga sekitar, Karena ketika ada masyarakat yang ingin menikahkan anaknya dan usianya belum mencukupi maka akan dimediasi oleh kalebun (kepala desa) dan apel, dengan maksud orangtuanya tidak mendesak pemerintah desa untuk menikahkan anaknya di usia dini, anaknya bias melanjutkan sekolah dan orangtuanya menahan keinginannya untuk menikahkan anaknya.

\section{Peraturan desa (perdes) tentang wajib belajar}

Peran desa yang sangat penting sekali adalah membuat peraturan desa tentang wajib belajar 12 tahun, demi mewujudkan zero drop out dan mencegah pernikahan anak. Upaya ini merupakan upaya yang sangat strategis dilakukan oleh pemerintah desa. Dengan tujuan masyarakat tidak ada yang putus sekolah dikarenakan oleh nikah di usia dini.

\section{SIMPULAN}

Nikah anak terjadi dengan ragam bentuk, ada nikah sirri, ada nikah melalui prosedur yang ada, yaitu meminta dispensasi melalui KUA ke pengadilan Agama. Terdapat beberapa factor penyebab nikah anak : kemauan sendiri, takut terjadi fitnah, khawatir nenek atau kakeknya tidak nututi, tradisi abhekalan (tunangan), dan didesak oleh pihak lakilaki.Adapun dampak nikah anak yang terjadi di Kecamatan Rubaru : putus sekolah atau drop out, kekerasan dalam rumah tangga yang menyebabkan pada perceraian, dan kesehatan ibu dan anak. Sedangkan peran pemerintah 
KHAZANAH MULTIDISIPLIN

VOL 1 NO 22020

https://journal.uinsgd.ac.id/index.php/kl

desa yang dilakukan adalah sosialisasi tentang dam pak nikah anak kepada masyarakat, meningkatkan peran kepala dusun, adanya pendidikan kesehatan reproduksi remaja, adanya forum mediasi untuk menunda nikah di usia dini, dan peraturan desa tentang wajib belajar 12 tahun.

\section{Penghargaan}

Peneliti mengucapkan terimakasih kepada LPPM STKIP PGRI Sumenep, pemerintah desa Mandala, karangnangka dan Tambaksari Kecamatan Rubaru, KUA Kecamatan Rubaru, para responden yang sudah berkenan memberikan informasi untuk kelengkapan data peneliti.

\section{Konflik Kepentingan}

hasil penelitian ini sangat bebas dari konflik kepentingan apapun, tentunya ada misi utama yaitu meminimalisir angka nikah anak yang terjadi di Kecamatan Rubaru khususnya dan Kabupaten Sumenep secara umum.

\section{DAFTAR PUSTAKA}

Ali, Mukti. Dkk. (2015). Fikih Kawin Anak; Membaca Ulang Teks Keagamaan Perkawinan Usia Anak-anak. Jakarta: Rumah Kitab

Badan Statistik Kabupaten Sumenep Tahun 2018

Djamilah, Reni Kartikawati (2014). Dampak Perkawinan Anak di Indonesia, Jurnal Studi Pemuda Vol. 3 No. 1, 1-16

Mubasyaroh (2016). Analisis Faktor Penyebab Pernikahan Dini dan Dampaknya bagi Pelakunya, Jurnal Pemikiran dan Penelitian Sosial Keagama an, Vol. 7 no. 2, 386-411

Candraningrum Dewi dkk, (2016). Takut akan Zina, Pendidikan Rendah, dan Kemiskinan :Status Anak Perempuan dalam Pernikahan Anak di Sukabumi Jawa Barat. Jurnal Perempuan, Vol 2.

Mies Grijn dkk, (2016). Pernikahan Anak di Sukabumi Jawa Barat. Jurnal Perempuan Vol 21 No 1.

Mohammad (2011),Perkawinan Anak di Bawah Umur (Sebuah Kajian PerspektifHukum Islam).JurnalAl-Ihkam Vol 6 No 2 Desember 2011.

Sherlin Darondos (2014), Perkawinan Anak di Bawah Umur dan Akibat Hukumnya.Jurnal Lex et Societatis Vol II/No. 4/Mei/2014.

Undang-Undang Nomor 16 Tahun 2019 tentang perubahan UndangUndang No. 1 Tahun 1974 tentang Perkawinan.

Yin, Robert K. 2015. Studi Kasus Desain \& Metode. Jakarta: Rajawali Press 